Володимир Шпортько, викладач

Українська військово-медична академія, м. Київ

ORCID ID 0002-0805-4922

DOI: $10.33099 / 2617-1775 / 2020-02 / 351-362$

\title{
ПРОБЛЕМИ ФОРМУВАННЯ ПРОФЕСІЙНОӦ КУЛЬТУРИ І КОМПЕТЕНТНОСТІ МАЙБУТНІХ ВІЙСЬКОВИХ ЛІКАРІВ В МЕДИЧНИХ УНІВЕРСИТЕТАХ КРАЇН НАТО
}

У статті розглядається досвід формування професійної культури $і$ професійної компетентності майбутніх військових лікарів краӥн НАТО при підготовці їх у вищих навчальних закладах (ВНЗ), а також використання передового досвіду та нових підходів підготовки військових лікарів у (ВНЗ) Украӥни. Проведено аналіз системи професійних компетентностей у підготовиі військових лікарів, яка застосовується у США, Великобританії та країн північної Свропи, моделей та перспективних методів навчання. Одночасно здійснено вивчення форм роботи у досягненні культурної компетентності та етичної освіти у системі підготовки майбутніх лікарів. Розглянуто схожість та відмінності освітнього прочесу навчання військових лікарів краӥн-партнерів північноатлантичного альянсу.

Ключові слова: професійна культура; професійна компетентність; студенти медичних навчальних закладів; офічери - лікарі; система навчання; ефективність підготовки.

Постановка проблеми. Інтеграційні процеси у системі військовомедичної освіти країн НАТО набули реальних обрисів зважаючи на сучасний інформаційний простір, необхідності досягнення взаємосумісності і цілей партнерства. 3 метою досягнення якісної взаємодії у мультикультурному середовищі країн-партнерів північноатлантичного альянсу направлено систему стандартів НАТО у галузі військової медицини АJP-4 (остання редакція від 11.09.2019 р.). Для Збройних Сил України врахування досвіду країн НАТО щодо впровадження передових методик у навчанні майбутніх військових лікарів, підвищення професійної культури та компетентності має важливе практичне значення.

Аналіз досліджень i публікацій. Історія розвитку медицини у західноєвропейських країнах тісно пов'язана із філософським осмисленням проблем медичної етики лікаря, їі ролі у системі медичних знань. Не менш важливим $є$ питання суто професійної компетентності лікаря. Питання військової етики висвітлювали у своїх роботах західні вчені Вольмут Р., Вортел Е., Кук М.Л., Ван Баарле Е.М., Босш Д., Робінсон П., В.К. Мак Вільямс, Г.Д. Міад. Аспекти професійної культури та етики військових лікарів розглянуті у дослідженнях Мартин С.М., Брикнелл К.Б., Бентанкур Д. Р., Грин А., Карільо Д.Е., Самуель Д. Малоней, Г.Д. Міад, Малтеруд К.

Питання формування професійної компетентності лікарів у країнах НАТО розкриті у роботах Адріан Ж.Х., Амброуз С.Й., Баррет Т.Д., Бетанкур Д.Р., 
Грин А.Р., Гудман Н.Р., Сторн Г., Как Р.С., Кук Д.А., Де Лоренцо Р.А., Такра Р.Д. та ін.

Мета статті. Проаналізувати наявні джерела інформації та з'ясувати як проблема формування професійної культури і професійної компетентності військових лікарів розглядається і використовується у процесі підготовки військових лікарів у вищих медичних закладах країн НАТО. Виявити які напрями підвищення професійної культури військових лікарів західних країн $\epsilon$ спільними і у чому існують розбіжності.

\section{Методи дослідження.}

Для розв'язання завдань дослідження використані методи теоретичного i емпіричного аналізу наукової літератури, порівняння, класифікація, узагальнення і систематизація матеріалу.

Виклад основного матеріалу. Проблема формування професійної культури та етики майбутніх військових лікарів завжди була у полі зору підготовки військових фахівців країн НАТО. Результати вивчення літератури показали що країни північноатлантичного альянсу певною мірою співпрацюють у галузі військо-медичної підготовки.

Питаннями професійної культури та етики майбутніх військових лікарів займаються безпосередньо навчальні медичні заклади, в окремих випадках, участь приймають громадські організації, спілки ветеранів, меценати. Достатньо великий вплив на моральні установки військовослужбовців, їх культуру мають релігійні конфесії включно із службою військових священиків (капеланів), зокрема таких країн як США, Канада, Велика Британія.

Військово-медичні служби та установи через Комітет керівників військомедичних служб країн HATO (COMEDS) iз 1994 року мають налагоджене міжнародне військове співробітництво у галузі розробки та координації військово-медичних питань підготовки, та надання Військовому комітету HATO рекомендацій у цій галузі [1]. Комітет (COMEDS) координує свою роботу з іншими органами НАТО, задіяними у медичній галузі зокрема

Агентством НАТО з питань стандартизації, Спільним медичним комітетом, медичних радників Верховних командувачів ОЗС НАТО, Комісією 3 людського фактора і медичних питань Науково-технічної організації, Центром зброї масового знищення [2]. Підпорядковані COMEDS робочі групи допомагають Комітету у виконанні низки завдань, зокрема військовопрофілактичної медицини, військової психіатрії, медичної підготовки, медичних інформаційних систем.

В останні роки міжнародне військово-медичне співробітництво НАТО розширилось за участю не тільки країн НАТО а і низки інших країн світу, які залучаються до ширшої міжнародної кооперації. Це продемонстровано залученням різних країн світу до Міжнародного комітету військової медицини (ICMM) і Центру наукових та педагогічних досліджень (CISM).

Цікавим є досвід співробітництва вищих медичних закладів Північної Європи [3] щодо підготовки майбутніх військових лікарів, підвищення їх професійної культури і компетентності, зокрема Норвегії, Швеції, Фінляндії, Бельгії, Данії, Нідерландів. Зазначені північноєвропейські країни мають свої 
національні особливості у системі підготовки майбутніх військових лікарів, але мають і свої власні шляхи державної підтримки підготовки і відповідно, різний обсяг виділених цільових ресурсів. 3 метою систематизації досвіду у підготовці майбутніх військових лікарів, підвищення їх професійної культури та компетентності, рішенням Ради старших військових хірургів північноєвропейських країн (Начальників медичних служб країн) у 2005 році було проведено наукове дослідження із використанням контент-аналізу [4]. Результати дослідження дали відповіді на три дослідницькі питання, які були згруповано у шість категорій. Перша група питань стосувалась схожості та відмінностей у освіті та навчанні. Друга група, розглядала проблеми у навчанні та підготовці, в межах обсягу розповсюджених військових травм. Третя група, вивчала погляди на систему впровадження електронного навчання та збільшення технологічного навчання.

Досвід північноатлантичних країн свідчить про належну увагу до здійснення селекції кандидатів для подальшого навчання у якості майбутніх військових лікарів. Зокрема, були створені підтримуючі структури для набору i навчання медичних працівників військової медицини, такі як політична підтримка, належні ресурси та тісна співпраця університетів і лікарень із травматичними центрами. Були і відмінності у вирішенні завдання підготовки військових лікарів Північних країн. Наприклад, Данія розробила систему набору персоналу, яка пропонувала лікарям спеціалізацію 3 хірургії під час базової медичної освіти та вибір різних форм контрактів у поєднанні 3 постійними посадами в структурах Міністерства оборони після закінчення навчання. Внаслідок такої роботи у студентів встановлювались тісні стосунки 3 лікарями, персоналом, починаючи 3 університетських років, що продовжувалось у подальшому протягом років служби у збройних силах країни.

Результати дослідження показують що формування професійної культури майбутніх військових лікарів у північноєвропейській військовій медицині проходить в першу чергу через освітню культуру, яка відзначається сталою військовою традицією. 3 даною метою проводять короткі теоретичні інструктажі, практичні заняття, які тривають протягом визначеного інтенсивного курсу у навчальні часи. Респонденти в ході опитувань свідчили про належний рівень педагогічної освіти, високий рівень академічних наук, керівників курсів і викладачів. Однак, в окремих випадках, зауваження були висловлені на недостатній практичний досвід викладачів, пов'язаний із можливістю участі їх у військових миротворчих місіях або досвіду роботи у зонах військових конфліктів.

Наприклад, у Норвегії, особливу увагу заслуговувала командна робота військових лікарів, підкреслювалось важливість розвитку військово-медичної освіти в рамках певної організації. Опитувані зазначили на важливість процесу управління в команді, особливо в операційному середовищі, як виконання спільного завдання із використанням професійних компетенцій усіх членів команди. Командна робота це реалізована модель управління невідкладною 
медичною допомогою як у мирний час, так і готовність до дій у воєннопольових умовах.

Міжнародне співробітництво в рамках військово-медичної освіти для майбутніх військових лікарів було встановлено за допомогою мереж, пов'язаних із зовнішніми курсами, такими як Battlefield Advanced Trauma Life Support (BATLS), Advanced Trauma Life Support (ATLAS), Хірургічна підготовка військових операцій (MOST) та остаточна хірургічна травма (DSTC).

Досліджуючи професійну культуру майбутніх військових лікарів у північних країнах НАТО були визначені проблемні питання за результатами моніторингового дослідження. Викладачі вищих медичних закладів потребують досвіду приближення (спорідненості) до навчального середовища, розвитку індивідуальних навичок військової медицини, досвіду роботи у миротворчих місіях.

Цікавим напрямком дослідження проблем професійної компетентності та культури військових лікарів північних країн Європи було використання електронного навчання у військовій медицині. Дослідження визначило три проблеми: відсутність компетенцій у поєднанні освітніх підходів; як застосовувати електронне навчання у противазі із практичним навчанням; як впливає підвищене технологією навчання на потенціал підтримки інновацій.

Опитувані респонденти із Данії, Фінляндії та Норвегії зазначили що їм не вистачає загального огляду розробки освітніх підходів та застосувань цифрової підтримки для досягнення сталих знань у військовій медицині та застосування у майбутній практиці в підрозділах. Недостатньо встановлена співпраця 3 цивільною медичною освітою та навчальним середовищем.

Респонденти, в ході опитування визначили проблемним питання яке постало в системі електронного навчання, саме відсутність педагогічних i навчальних компетенцій. Інтерв'юери з Фінляндії, Норвегії та Швеції зазначили що веб-освітні методики, система курсів в Інтернеті, без традиційних лекцій і дискусій віч-на-віч не завжди мають якісний рівень. Проблема існує i в можливості доступу до Інтернету у військових частинах. Опитувані респонденти із Данії вважають що традиційна система віч-на-віч без дистанційного навчання найкраща, коли їх участь у дискусійних групах, практичних заняттях дає бажаний результат.

Об’єднання освітніх підходів у стійку стратегію освіти i навчання передбачає перехід від традиційного навчання майбутніх військових медиків до застосування новітніх цифрових технологій 3 метою досягнення змішаного навчання [5]. Ключовим питанням якісного електронного навчання та змішаного навчання на думку фахівців НАТО $є$ поєднання навчальної компетентності з контекстуальним розумінням стратегіі і те як застосовувати цифрові навчальні методи.

Медичні працівники військово-медичних закладів західних країн мають відповідну освіту та наукову спеціалізацію, тобто традиційну культуру військово-медичної освіти, але у них часто не вистачає часу на підвищення належного рівня освіти і навчання. Сучасні підходи до освіти та навчання, як 
правило, передбачають перехід акценту від діалогу спрямованого на викладача на діалог направлений на учасника та використовує цифрову підтримку, як підтримку навчальних процесів і методів співпраці [6].

В умовах коли існуючий досвід підготовки військових лікарів $\epsilon$ недостатнім, стратегія змішаного навчання для освіти буде важливою [7]. Вибір конкретної стратегії навчання залежить від таких факторів як ефективність та витрати. Будь яка окрема стратегія навчання не може замінити потреб окремої людини чи підрозділу, тому важливо використовувати комбінацію стратегій, де кожна має переваги у певних умовах [8].

Поліпшення якості в освіті та навчанні залежить від якості передачі результатів освіти у практику. Наведене вище дослідження проведене північними країнами Європи показало недостатню оцінку та зворотній зв'язок систем навчання та навчання майбутніх військових лікарів 3 військовою системою навчання, що знижує якість існуючих курсів і програм.

Важливе значення для формування професійної культури майбутніх військових лікарів має етична освіта. Наприклад, за досвідом у Збройних Силах Нідерландів, налагоджено чітку систему етичної освіти військовослужбовців всіх категорій. 3 даною метою застосовано введення курсу підготовки інструкторів з військової етики. Навчання діє протягом дев'яти днів, чотири рази на рік. Навчання інструкторів з етики проводить факультет воєнних наук Академії оборони Нідерландів. Лікарі Збройних сил Нідерландів, в свою чергу, проходять лекційний курс з військової етики [9].

Традиційно важливим для збройних США є участь у етичному вихованні майбутніх військових лікарів військових священників. Проблема етики військовослужбовця і безпосередньо військового лікаря гостро постала у ході війни у В'єтнамі, наприклад у 1969 році за участі збройних Сил США [10], за прикладом брутальної поведінки та знищення мирного населення у громадах Мілай (селище Сонгмі) та Мікхе. Після завершення війни у В'єтнамі виникло питання і потреба у вивченні наслідків трагічних подій у Сонгмі. Висновки поведінки та етики військовослужбовців найшли відображення у програмах військово-медичних закладів та вищих медичних закладів які готують військових лікарів, зокрема було запроваджено курс військової етики.

Етичне виховання військових лікарів США за настановами провідних військових капеланів країни [11] спрямоване на вивчення принципів етики та досягнення необхідних моральних установок поведінки. Протягом останніх десятиліть військово-медична академія та медичні центри США досягли позитивних зрушень у формуванні професійної культури та етики військових лікарів, показують ріст зацікавленості у навчанні етичним принципам [12]. В системі підготовки військових лікарів США більша частина лікарів (біля 70\%) готується у цивільних вищих навчальних закладах, де проходить невеликий курс із деонтології. Після третього курсу, студенти-медики які висловили бажання у подальшому служити у збройних силах, проходять збори терміном до двох місяців на яких включені заняття за тематикою етики військового лікаря. У подальшому, після закінчення медичного факультету, лікарі при наявності отриманих ними офіцерських звань навчаються у дворічній 
інтернатурі при окремих військових госпіталях. У цей період навчання вони безпосередньо стають частиною військово-медичних колективів, де наголос іде на командну спеціалізовану роботу. Завершення навчання військового лікаря у США відбувається шляхом проходження шестимісячного курсу навчання у військово-медичних центрах, де визначена за програмою низка лекцій i семінарів із військової етики і деонтології [13], управління військовими колективами і лідерства.

При підготовці військових лікарів у Великій Британії також застосовуються комбінована система цивільної та військової освіти на зразок США, але терміни навчання відмінні. Для того щоб стати офіцером необхідно пройти навчання у Королівській воєнній академії, де термін навчання у залежності від спеціалізації від 10 до 44 тижнів. Існує також інститут воєнномедичного кадетства, де курсанту присвоюється офіцерське звання молодший лейтенант. Протягом всього навчання слухачі отримують достатні знання із деонтології, основ психології і педагогіки, використовується традиційна британська система навчання i виховання. Особлива увага приділяється навчанню практиці роботи в спеціальних умовах, як в національних, так i багатонаціональних військових організацій [14], вивченню досвіду участі у миротворчих місіях, інших військових операціях, а також підтримці військових традицій і ритуалів.

В медичній службі Бундесверу питанням професійної культури, а саме досягненню етичних стандартів, приділяється особлива увага. Для Німеччини постановка проблеми $є$ актуальною, враховуючи обставини у яких опинились військові лікарі у ході першої та другої світової війни. Наприклад, у ході другої світової війни, медичні працівники та вчені були заідеологізованими націоналсоціалізмом при виконанні своїх наукових або професійних амбіцій. Вони дозволили себе експлуатувати, виконували злочинні накази. Військовий медик фашистського вермахту опинився у обставинах виконання військової необхідності, де існувала етична прірва, а інколи військові лікарі ставали співучасниками злочинів.

У сучасному Бундесвері армія під контролем парламенту, участь у міжнародних операціях та місіях відбувається у відповідності до міжнародного права. Враховуючи правила Женевської конвенції, принципу нейтралітету для до військових лікарів як не комбатантів, заборона їх безпосередньої активної участі в бойових діях знаходяться під питанням (Місія у Афганістані). Такий стан технічного застосування військових лікарів у військових операціях під егідою НАТО, переваги юридичної виключної ситуації призводить до «слизького схилу» [15]. Мова іде про те що у медичній службі Бундесверу виявляється небезпека можливості роздвоєння між медичною етикою лікарів та воєнною необхідністю використання їх у бойових умовах. Відповідно до наукових робіт, пов'язаних із професійною культурою серед військових медиків сучасної Німеччини, розглядаються етичні конфлікти що виникають у внутрішніх та зовнішніх відносинах медичної служби, тобто між членами медичної служби або у відношенні до третіх сторін. Етичні принципи «не нашкодити» та «добро», можливість автономії пацієнта при виборі кращого 
лікаря, методики лікування а також позиції між медичною етикою та воєнною необхідністю в полі досліджень та практичного застосування.

В країнах НАТО достатньо поширеним $є$ термін «культурна компетентність» у якій більшість науковців виділяють такі компетенції викладачів та майбутніх лікарів-студентів вищих медичних навчальних закладів а саме: 1) здатність критично розуміти власні цінності та переконання; 2) здатність говорити про інших людей без стереотипів, без ознак дискримінації; 3) співчувати та моральна підтримка пацієнтів незалежно від етнічних та расових ознак; 4) знання етнічних та соціальних ознак людей; 5) здатність враховувати соціальні та культурні особливості пацієнта що може мати відношення до хвороби пацієнта; 6) можливість мотивації студентів та залучення їх до дослідницької роботи [16]. Для того щоб організація або структура стала культурно компетентною вона повинна мати такі елементи що дозволяють культурну самооцінку, освідомлення динаміки взаємодії культур, культурних знань, надання відповідних послуг які відображають культурне різноманіття [17]. Вивчення педагогічних досліджень країн НАТО щодо професійної компетентності майбутніх військових лікарів дає змогу визначити такі складові як: суто професійна підготовка, професійно-комунікативні якості, набуття знань з психології і педагогіки, рівень методичної підготовки.

Оскільки в країнах НАТО більше представлено різноманіття етнічних груп населення, збільшуються міграційні процеси, це робить новий виклик у роботі військових лікарів. Аналіз дослідження проведеного в період з 2008 по 2014 рік у Каліфорнійських університетах Сан-Франциско та Берклі і Стенфордському університеті, виявило що у опитаних пацієнтів існує відчуття дискримінації у сфері охорони здоров'я [18]. Лікарі не завжди беруть до уваги такі аспекти як соціально-економічний статус пацієнта, статус емігранта, оточуючого середовища, часто схильні до стереотипів або упереджень у своїй поведінці [19]. Тому особлива увага звертається на розвиток навичок стратегій спілкування з пацієнтами, взаємоповаги у процесі спілкування серед лікарів однієї медичної установи. Розвиток навичок професійної культури лікаря $\epsilon$ активним процесом який вимагає перегляду власної внутрішньої системи переконань [20].

У США серед робіт що розглядають професійну культуру лікарів достатньо уваги приділяють напрямку культурної компетенції у лікуванні пацієнтів різних культур та етнічних груп. Результати дослідження свідчать про те що серед пацієнтів достатньо великий відсоток смертності у групах емігрантів із Латинської Америки, афроамериканців. Інколи лікарі упереджено ставляться до пацієнтів національних меншин, приділяють їм мало уваги [21]. Окремі штати (Вашингтон, Каліфорнія, Коннектикут, Нью-Джерсі, НьюМексіко) прийняли закон, який вимагає від усіх лікарів проходження не менше шести годин навчання із культурної компетентності для лікарів [22].

Відповідно до стандарту LCME (Комітет зв'язку та медичної освіти) для визначення рівня культурної компетенції «викладачі та студенти повинні продемонструвати розуміння того, як люди різних культур та системних переконань сприймають стан свого здоров'я або хвороби, реагують на різні 
симптоми, захворювання і методи лікування» [23]. Всі медичні школи та університети США включили у свої навчальні програми викладання культурної компетентності. Відповідно вимог відпрацьовуються учбові плани з культурних компетенцій, які дозволяють налагодити взаємодію між пацієнтами та лікарями, надавати високоякісну та культурно компетентну допомогу пацієнтам та їх родинам [24].

У США існує проблема із знанням англійської мови серед великої кількості емігрантів. За статистикою перепису населення у США у 2011 році 23,5 мільйонів людей вважались людьми із обмеженим знанням англійської.

Виникає гостра потреба залучення перекладачів різних національних мов для надання перекладів та мовної допомоги як лікарям, так і пацієнтам, досягнення вимог стандартів CLAS (національні стандарти у сфері охорони здоров’я), які передбачають надання культурних та лінгвістичних послуг.

Дослідження наведене у статті не вичерпує всіх аспектів формування професіональної культури та компетентності майбутніх військових лікарів у вищих медичних навчальних закладах країн НАТО та їх партнерів. Вивчення досвіду вищих медичних закладів північноатлантичного альянсу може бути використане у подальших перспективних дослідженнях та врахуванні при підготовці військових лікарів України.

Висновки та перспективи подальших досліджень. Аналіз матеріалів наведених у статті засвідчив що в країнах НАТО приділяють велику увагу теоретичним і прикладним дослідження формування професійної культури та культурної компетентності медичних працівників. В той же час, проблеми формування професійної культури і компетентності військових лікарів у різних країнах мають свої національні особливості, різний рівень розробки. У період збільшення світових міграційних процесів, виконанням операцій 3 підтримки миру на різних континентах за участю військових контингентів і залученням медичного персоналу підвищує вимоги до професіональної культури i культурної компетентності військових лікарів.

Наведена інформація із досвіду країн НАТО щодо підготовки майбутніх військових лікарів у вищих медичних закладах, формування їх професійної культури є корисною для подальшого поглибленого вивчення і використання у практичній діяльності. Тому «розв'язання проблем можливо лише на системній основі, з урахуванням трансформації українського суспільства та його воєнної сфери» [25].

Подальші дослідження проблеми покращення професійної культури i компетентності військових лікарів є актуальними для удосконалення системи підготовки лікарів у вищих медичних закладах та Українській військовомедичній академії.

Висновки та результати подальших досліджень щодо професійної культури військових лікарів, які готуються у вищих медичних закладах України допоможуть створити належні умови оптимізації навчального процесу, морально-психологічного забезпечення підготовки військових медиків. 


\section{ЛІТЕРАТУРА}

1. Довідник НATO Public Diplomacy Division NATO, 1110 Brussels, Belgium - 2006. C. 328

2. Довідник НATO Public Diplomacy Division NATO, 1110 Brussels, Belgium - 2006. C. 329

3. Річний звіт Північноатлантичного Комітету 2016. Defence DMo. NORDEFCO ANNUAL REPORT 2016.

4. Малтеруд К. Якісні методи медичних досліджень, умови, можливості, та проблеми. Вид: Угеск Лагер. 2005; 167(22) : 2377-80. PubMed Google Академія.

5. Сторн Г. Електронне навчання і можливості майбутньої освіти у галузі охорони здоров'я у Збройних Силах Швеції. Магістерська робота . Кафедра інформатики охорони здоров’я Університету Лінчепінга, 2013. PubMed Google Академія.

6. Кук Д.А. Елетронне веб-навчання: професіоналізм, мінуси та полеміка. Медична клініка. 2007; 7(1):37-42. Google Академія.

7. Де Лоренцо Р.А. Як нам слід готуватись. Mil. Med. 2005. 170(10):824-30.

8. Андерсон С. Сприйняття лікарями та медсестрами невідкладної долікарської допомоги. 2014.- С.61.

9. Ван Ваарле Е., Босш Д., Віддерсшовен Г., Вервешдж Д., Молевіджк В. Моральні дилеми у воєнному контексті: тематичне дослідження курсу підготовки інструкторів 3 військової етики. Журнал морального виховання, 44, 457-478. [Тейлор і Френсіс онлайн], [Web of Science], Google Scholar.

10. Мак Вільямс В.К. Військова честь після Малайї (Рада з релігійних та міжнародних справ. Нью Йорк) 1972.- С.70.

11. Міад Г.Д., Капелан (Генерал-майор США). Прихильність до доброчесності. Огляд університету Повітряних Сил. 28 (3). Березень - квітень 1977.- С.88.

12. Малоней С.Д. Теорія етики для військового спеціаліста. Огляд університету Повітряних Сил, 32 (3). Березень - квітень 1981.- С.88-71.

13. Кук М.Л. Військова етика та характер розвитку. Довідник з військової етики. Вид: Г. Лукас. Нью Йорк. Гугл ресурс вченого. 2015.

14. Мартин С.М., Брикнелл К.Б. Культурній виклик лідера у медицині. Альманах воєнної медицини. Оборонні медичні служби. https:/www.gov.uk/government/groups/defence-medical-services 13.08.2009.

15. Вольмут Р. Фахівці охорони здоров'я між військовою етикою та військовими обов'язками. Медичний Корпус. Міжнародний форум. Вип. 2. 2016. https://www.mciforum.com.

16. Горпініч T.I. Структура професійної компетентності у викладачів вищих медичних навчальних закладів у США. Ужгород. Вид: Говерла 2019. - Вип. 2(45).- С. 46-51 https://www.dspace.uzhnu.edu.ua/jspu/handle/lib/24857.

17. Бентанкур Д. Р., Грин А., Карільо Д.Е. Культурна компетентність у охороні здоров'я: нові основи та нові підходи. Нью Йорк. Фонд співдружності. Електронний ресурс.(ПДФ).2002.

18. Американська соціологічна асоціація. Вид. Science daily. 12.03.2019 .

19. Бентанкур Д.Р., Грін А.Р. Карильо Д.Е. Визначення культурної компетенції: практична основа для вирішення расових, етнічних розбіжностей у галузі охорони здоров'я. Звіти громадської системи охорони здоров'я. 118(4). 07.2003.- С. 293-302.

20. Культурна компетентність. Освіта у сфері соціальних послуг. https://www.humanservicesedu.org . 12.03.2019.

21. Штейнер Б. Неявні етнічні та расові упередження клініцистів та сприйняття медичної допомоги серед чорношкірих та латиноамериканських пацієнтів. Вид. Clinical Key. 11(1). 2013.- C 43-52.

22. Роберт С. Навчання лікарів культурній компетентності та відмінності у системі охорони здоров'я. Журнал безперервного навчання у медичних професіях.31(3). С.196-206. Doi: 10.1002/chp 20127. PMID 21953661. 
23. Функції та структура медичної школи: стандарти акредитації програм медичної освіти, що спрямовані на отримання ступеню доктора медичних наук. Вид. Асоціація медичних коледжів. Вашингтон. Округ Колумбія. 2013.

24. Навчання культурній компетентності студентів-медиків. Вид. Асоціації американських медичних коледжів (ААМС). Вашингтон. Округ Колумбія. 2005.

25. Чорний В.С. Військова організація України та перспективи розвитку: монографія. Ніжин: тов. «Видавництво «Аспект-Поліграф», 2009. - 368 с.

\section{REFERENCES}

1. Dovidnik HATO Public Diplomacy Division NATO, 1110 Brussels, Belgium - 2006.- C. 328.

2. Dovidnik HATO Public Diplomacy Division NATO, 1110 Brussels, Belgium - 2006.- C. 329.

3. Rithniy zvit Pivnithnoatlantithnogo Komitetu 2016. Defence DMo. NORDEFCO ANNUAL REPORT, 2016.

4. Malterud K. Yakisni metodi medithnih doslidgen, umovi, moglivosti, ta problemi. Vid: Ugesk Lager. 2005. 167(22) : 2377-80. PubMed Google Академія.

5. Storn G. Elektronne navthannia i moglivosti maibutnioi osviti u galuzi ohoroni zdorovia u Zbroinih Silah Shvetsii. Magisterska robota. Kafedra informatiki ohoroni zdorovja Universitetu Linthepinga. 2013. PubMed Google Академія.

6. Kuk D.A. Elektronne veb-nauthannia : profesionalizm minusi ta polemika. Medithna klinika. 2007; 7(1):37-42. Google Akadimija.

7. De Lorentso R.A. Jak vam slid gotuvatis. Mil. Med. 2005. 170(10): 824-30.

8. Anderson S. Sprijniattia likariam ta medsestrami nevidkladnoi dolikarskoi dopomogi. 2014.- C.61.

9. Van Vaarle E., Bosh J., Widershoven G., Verweij D., Molewijk B. Moralni dilemi u voennomu konteksti: tematityne doslidgennia kursu pidgotovki instruktoriv iz viyskovoi etiki. Jurnal voennogo vihovannia, 44. Vid. Teilor I Frensis online. [Web of Science], Google Scholar.

10. Mak Uviljams V.K. Vijskova thest pislia Malaji (Rada iz riligiynih ta mignarodnih sprav). New York. 1972.- C.70.

11. Miad G.D., Kapelan ( Maj. Gen. USA). Prohilnist dobrothesnisti. Ogliad universitetu Povitrianih Sil. 28(3). Berezen-kviten 1977.- C.88.

12. Maloney S.D. Teoria etiki dlia viyskovo spetsialista. Ogliad universitetu Povitraanih Sil. 32 (3). Berezen-kviten 1981.- C.88-71.

13. Kuk M.L., Vijskova etika ta harakter rozvitku. Dovidnik iz viyskovoi etiki. Vid: G.Lukas. New York. Googl resurs vthenogo.2015.

14. Martin C.M., Bricknell K.B. Kulturniy viklik lidera $\mathrm{v}$ meditsini. Almonah voennoi meditsini. Oboronni medithni slugbi.

15. Volmut R. Fahivtsi ohoroni zdorovia mig viyskovou etikou ta viyskovimi obovizkami. Medihniy korpus. Miznarodniy forum.Vid:2.2016 https://www.mci-forum.com.

16. Gorpinith T.I. Struktura profesiynoi kompetentnosti u vikladathiv vishthih medithnih navthalnih zakladiv u USA. Ughorod. Vid:Goverla, 2018. Vip. 2(45).- C.46-51.

https://www.dspace.uzhnu.edu.ua/jspu/handle/lib/24857.

17. Bentankur D.R., Grin A., Karilljo D.E. Kulturna kompetentnist u o Oroni zdorovia: novi osnovi ta novi pidhodi. New York. Fond spivdrugnosti. Elektronniy resurs (PDF).2002.

18. Amerikanska sosiologithna assisiatsia. Vid. Science daily. 12.03.2019.

19. Bentankur D.R., Grin A., Karilljo D.E. Viznathennia kulturnoi kompetentnosti: praktihna osnova dlia virishennia rasovig, etnothnih rozbignostey u galuzi ohoroni zdorovia. Zviti gromadskoi sistemi ohoroni zdorovia. 118(4). 07.2003.- C. 293-302.

20. Kulturna kompetentnist. Osvita u sferi sotsialnih poslug. https://www.humanservicesedu.org . 12.03.2019.

21. Shteiner B. Nejavni etnithni ta rassovi uperedgennia klinitsistev ta spriynattia medithnoi dopomogi sered thornoshkirih ta latinoamerikanskih patsientiv. Vid: Clinical Key. 11(1). 2013.-C 43-52. 
22. Robert S. Yavthannia likariv kulturniy kompetentnosti ta vidminnosti u sistemi ohoroni zdorovia. Gurnal bezperervnogo navthannia u medithnih profesijah. 31(3). C.196-206. Doi: 10.1002/chp 20127. PMID 21953661.

23. Funksiita struktura medithnoi skoli:standarti akreditasii program medithnoi osviti, sho spriamovani na otrimannia stupeniu doktora medithnih nauk.Vid: Assosiatsia medithnih koledgiv. Vashington. Okrug Kolumbia. 2013.

24. Navthannia kturniy kompetentnosti studentiv-medikiv. Vid: Assosiatsia amerikanskih medithnih koledgiv (AAMC). Vashington. Okrug Kolumbia.2005.

25. Thorny V.S. Viyskova organizatsia Ukraini ta perspektivi rostu:monografia. Vid: Nigin: tov. «Vidavnitstvo «Aspekt-Poligraf». 2009. - 368 c.

\section{РЕЗЮМЕ}

\section{Владимир Шпортько,} преподаватель

Украинская военно-медицинская академия

\section{Проблемы формирования профессиональной культуры и компетентности будущих военных врачей в медицинских университетах стран НАТО}

Целью статьи является исследование вопроса формирования профессиональной культуры и культурной компетентности военных врачей в медицинских университетах стран НАТО. Для этого применялись общенаучные методы исследования. Наличие военных конфликтов в мире, постоянный рост миграции населения повышает актуальность углубления сотрудничества внутри североатлантического альянса. Система подготовки будущих военных врачей в медицинских университетах стран НАТО имеет много общего, в тоже время существуют определенные национальные отличия.

Качественная подготовка военных врачей стран НАТО невозможна без повышения их профессиональной культуры и компетентности. Университеть стран НАТО и западной Европы работают над повышением качества профессиональной культуры военных врачей в ходе их обучения в высших медицинских заведениях, что имеет прикладное практическое значение.

Учитывая евроатлантические устремления Украины, есть объективная необходимость усовершенствования системы военно-медицинского образования 6 медицинских университетах страны и Украинской военно-медицинской академии с учетом изучения и использования опыта стран НАТО.

Ключевые слова: профессиональная культура; профессиональная компетентность; студенты медицинских заведений; офицеры-врачи; система обучения; эффективность подготовки.

\section{SUMMARY}

Volodymyr Shportko, Teacher

Ukrainian Military Medical Academy

Problems of formation of professional culture and competence of future military doctors in medical universities of NATO countries

Introduction. The professional culture and competence of future military doctor encompasses professional, general-cultural, ethical values and is of great practical importance.

Purpose. To analyze the scientific sources and publications of NATO and Western European scientists on the formation of the professional culture and competencies of future military doctors at 
NATO medical universities. The article reveals which areas of the professional culture of NATO military doctors are common and what are the differences.

Research methods. Methods of theoretical, empirical analysis scientific literature, publications, comparison, classification, generalization and systematization of the material were used to solve the problems of the research.

Results. The article covers aspects of the training of future military doctors at NATO and Northern European institutions of higher education. The example of the USA, Great Britain, Germany and Nordic countries shows the scientific experience and experience of forming the professional culture and competence of doctors. The pedagogical features of the process of educational and training of future military doctors are highlighted, with emphasis on the criteria of improving their professional competence and culture. The results of recent scientific studies of the North Atlantic countries in the field of the study of the professional culture and ethics of physicians in the course of their education and medical practice have been shown quite deeply.

Scientific novelty and practical significance of research results. An attempt was made to show and analyze the amount of scientific work in NATO Western Europe on the formation of professional culture and ethics of the military doctor, his professional competence in the face of today's global challenges related to the increasing military threats, increasing migration processes. The novelty of the study is the display analytical material based on the results and conclusions of studies on professional culture and competence, especially in countries such as United States and North European countries.

It summarizes the similarity of experience, methodologies and approaches acquired in NATO's medical universities in ethical education, professional competence, and highlights the existing differences. The author emphasizes the need to constantly study the experience of the countries the North Atlantic Alliance in matters of competence formation and professional culture of military doctors, taking into account the course of Ukraine on joining NATO. What is also important is that the process of reforming the military-medical service of the Armed Forces of Ukraine is continuing, and the work on achieving the goals of NATO partnerships and standards is increasing, which requires comprehensive scientific justification and recommendations in solving the set tasks.

Conclusions and prospects for future research. Scientific research at NATO and Western Europe show that the growth of the professional culture and competence of future military doctors greatly improves the quality of provided medical care in the countries where doctors are trained, and enables them to perform peacefully peacekeeping missions.

The experience of NATO countries in the training of military doctors is of practical importance for Ukraine, in view of the continuation of Russian - Ukrainian war in the eastern Ukraine, which required not only a sufficient number of highly qualified military doctors, but also the acquisition of appropriate professional competence and professional culture. Continuation of research on the enhancement of the professional culture and competence of military physicians is time consuming.

Conclusions on the results of future research on the formation of professional culture in the processes of training future military doctors for the Armed Forces of Ukraine are of practical importance for the optimization of the educational process, the use in the daily work of doctors in part and medical institution of the Armed Forces and other security forces of Ukraine.

Key words: professional culture; professional competence; students of medical schools; officers - doctors; training system; effectiveness of training. 